Przegląd Badań Edukacyjnych Educational Studies Review

ISSN 1895-4308

nr 23 (2/2016), s. 195-210

METAANALIZY

BADAŃ

EDUKACYJNYCH

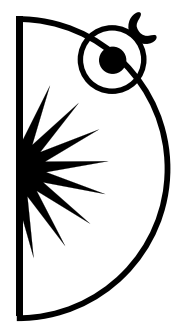

Anna Dębska

Klinika Psychiatrii i Rozwoju Osobistego, GabClinic.com, Warszawa, e-mail: ad@wp.eu

Barbara Jacennik

Wyższa Szkoła Finansów i Zarządzania w Warszawie; e-mail: bjacennik@gmail.com

\title{
Programy nauczania uważności dla dzieci i młodzieży - z perspektywy szkolnictwa polskiego
}

http://dx.doi.org/10.12775/PBE.2016.079

\section{Mindfulness Training Programs for Children and Youth - a Review from the Perspective of Polish Education}

\begin{abstract}
Mindfulness training program is a type of psychosocial intervention realized, among others, in schools and preschools for students aged from 4 to 18 years and older. The current interest in mindfulness sessions results from: (1) reports of their positive impact on mental health, coping with problems and distribution of attention; (2) the alarming statistics, e.g. WHO, concerning mental health of young people; (3) the need for interventions based on scientific evidence. The main goal of the article is to present mindfulness training programs for children and youth in Europe and North America, focusing on the programs whose effectiveness has been demonstrated in evidence based research. Next goal was to present a review of the main results of meta-analyses of studies on the effects of mindfulness training for children and youth. Finally, the conditions and the possibilities for implementing mindfulness training programs in Polish schools were discussed. It was concluded that the literature review and analysis of research results indicate that there are significant benefits of mindfulness training programs for the students' psychosocial functioning. The mindfulness programs could be effectively implemented within the Polish education system.
\end{abstract}

Keywords: mindfulness, mindfulness training, psychosocial intervention, mental health programs, school/preschool education 


\section{Wprowadzenie}

Według danych Światowej Organizacji Zdrowia (WHO, 2005), 20\% dzieci i młodzieży doświadcza problemów ze zdrowiem psychicznym. Informacja o stanie zdrowia psychicznego polskich uczniów jest fragmentaryczna i niepełna (Tabak, 2014). Brakuje rzetelnych danych dotyczących rozpowszechnienia problemów psychicznych wśród dzieci i młodzieży w Polsce (Namysłowska, 2013). Szacuje się, że ok. 9\% osób z tej grupy cierpi na szeroko pojęte zaburzenia psychiczne (Wolańczyk, 2002). Zgodnie z danymi Głównego Urzędu Statystycznego za rok 2014, niepokojący jest wzrost samobójstw wśród nastolatków (15-19 lat) w ciągu ostatnich 25 lat (GUS, 2014). Wiele danych wskazuje na wzrost zaburzeń depresyjnych, zaburzeń zachowania czy konsekwencji zażywania substancji psychoaktywnych (Namysłowska, 2013). Działania profilaktyczne w zakresie zdrowia psychicznego młodzieży wymagają wspólnego działania, zgodnie z celem „Narodowego programu zdrowia na lata 2016-2020 (projekt)”, jakim jest ,poprawa zdrowia psychicznego, w tym zapobieganie uzależnieniom behawioralnym" (2015).

Celem artykułu jest przedstawienie podstaw teoretycznych i zasad wdrażania programów interwencji psychospołecznej o charakterze treningu mindfulness (uważności) dla dzieci i młodzieży. Autorki dokonały przeglądu literatury na temat programów uważności już realizowanych w krajach angielskojęzycznych oraz podjęły próbę oceny możliwości wdrożenia takich programów w szkolnictwie polskim. Artykuł jest adresowany do pedagogów, psychologów i innych osób zainteresowanych nauczaniem i praktykowaniem uważności.

\section{Uważność mentalna - podstawowe pojęcia}

Radoń (2013) sugeruje, że pewną słabością pojęcia uważności jest to, że trudno je zdefiniować. Czy jest to rodzaj światopoglądu, treningu psychoprofilaktycznego, a może terapii psychologicznej? Na potrzeby niniejszego artykułu przyjęto, że mindfulness (uważność, uważność mentalna, uważna obecność) to zespół technik wspomagania zdrowia psychicznego, bazujący na uniwersalnych elementach światopoglądowych, mający zastosowanie w psychoprofilaktyce i terapii psychologicznej.

Uważność polega na intencjonalnym kierowaniu uwagą w taki sposób, aby uświadomić sobie własne stany mentalne i otoczenie - bez oceniania tego, co w owej chwili się pojawia. Jon Kabat-Zinn (2013) określa uważność jako szczególny rodzaj uwagi: świadomej, nieoceniającej i skierowanej na bieżącą chwilę: 
„pielęgnuje się ją przez celową koncentrację na rzeczach, nad którymi zwykle się nie zastanawiamy. Jest to systematyczny rozwój nowych rodzajów kontroli i mądrości w naszym życiu, oparty na naszych wewnętrznych zdolnościach, relaksacji, skupianiu uwagi, świadomości i percepcji” (Kabat-Zinn, 2013: 36).

Według Radonia „,elem stosowania technik uważności jest wykształtowanie takiej zdolności w podmiocie, aby zauważał pełną różnorodność bodźców zarówno wewnętrznych, jak i zewnętrznych. Stan uważności jest osiągnięty wtedy, gdy dana osoba swobodnie, po wyłonieniu się obiektu w jej umyśle i zaakceptowaniu go, potrafi ponownie powrócić do koncentracji np. na swoim oddechu. Stan ten jest formą oscylacji uwagi między doznaniami wewnętrznymi i zewnętrznymi. Systematycznie prowadzone ćwiczenia uważności pomagają w korygowaniu nieelastycznych i nawykowych wzorców myślenia, zachowania i odczuwania" (Radoń, 2013, s. 110).

Mindfulness wywodzi się z buddyzmu, w którym fundamentalne znaczenie ma praktyka medytacji, w której uważność, rozumiana jako uważna obecność lub pełnia uważności, jest jednym z istotnych elementów. Uważna obecność służy utrzymywaniu świadomości bieżących zdarzeń „chwila po chwili” (moment to moment awareness of present events).

Praktyka uważności jest stosowana $\mathrm{w}$ różnych podejściach terapeutycznych, również wychodzących od względnie odległych założeń. W psychoterapii jest obecna m.in. w podejściu Gestalt, gdzie kładzie się nacisk na uświadamianie sobie doświadczania stanów psychicznych „tu i teraz”, po to, aby osiągnąć równowagę, rozwijać swój potencjał i wprowadzać pożądane zmiany w życiu (Chu, 1993) oraz w podejściu poznawczo-behawioralnym tzw. trzeciej fali (Wendt, 2015, 12 luty). Również w analizie transakcyjnej, w której głównym założeniem terapii jest uczenie się autonomii, wykorzystuje się praktykę uważności w celu uczenia się bycia „tu i teraz” oraz rozpoznawania własnych doznań (Krajewska, 2016, 29 luty).

Zgodnie z wieloma koncepcjami filozoficznymi, psychologicznymi i religijnymi „tu i teraz” jest jedyną rzeczywistością, jakiej możemy doświadczać, i w której możemy w pełni, funkcjonalnie działać. Korzyści związane z uważnością są niejako wtórne w stosunku do możliwości doświadczania bogactwa i pełni bieżącej chwili.

\section{Programy nauczania uważności}

Najbardziej znana interwencja oparta na uważności (Mindfulness-Based Intervention) to program rozpoczęty w latach 70 . przez Jona Kabat-Zinna w Uni- 
versity of Massachusetts Medical Center pod nazwą Mindfulness Based Stress Reduction (MBSR). Program ten składa się z ok. 3-godzinnych spotkań grupowych odbywających się przez 8 tygodni. W programie wykorzystuje się następujące techniki uważności: kontrola oddychania, body scan, formalne siedzenie, koncentracja na codziennych rutynowych czynnościach, stosowanie łatwych elementów hathajogi (Radoń, 2013). Skuteczność MBSR w zakresie leczenia wielu zaburzeń psychicznych i somatycznych potwierdzono licznymi badaniami. W szczególności zweryfikowano wpływ na leczenie zaburzeń lękowych (Kabat-Zinn i in., 1992), depresji (Segal i in., 2002), uzależnienia od substancji psychoaktywnych (Marlatt i in., 2002), zaburzeń odżywiania (Kristeller i in., 1999), chorób skóry (Kabat-Zinn i in., 1998), syndromu przewlekłego zmęczenia i wypalenia (Flook i in., 2013) oraz nowotworów (Cramer i in., 2012). Od 2004 r. program MBSR jest rekomendowany przez brytyjski National Institute for Health and Clinical Excellence w leczeniu nawrotów depresji.

Drugim silnie rozwijającym się nurtem nauczania mindfulness jest zapoczątkowany w 1992 r. program oparty na MBSR i rozszerzony o elementy poznawcze - Mindfulness Based Cognitive Therapy (MBCT) opracowany przez Zindela Segala, Marka Williamsa oraz Johna Teasdeale'a. MBCT początkowo był stosowany dla osób z nawracającą depresją. W wielu krajach, również i w Polsce, odbywają się coraz liczniej warsztaty MBSR zgodnie z autorskim programem Kabat-Zinna, objętym systemem certyfikacji. Organizowane są również kursy certyfikujące dla nauczyli zarówno MBSR, jak i MBCT przygotowujące do prowadzenia warsztatów uważności. Pierwszy kurs nauczycielski MBSR/MBCT w Polsce został realizowany w latach 2010 i 2011 w Warszawie, w kolejnych latach były podejmowane dalsze działania tego typu.

Uczenie uważności ma na celu poprawę jakości życia poprzez dystansowanie się od nawykowych myśli i zachowań. Drogą do uzyskania dystansu do tego, co przynosi ból i cierpienie jest nakierowanie na to uwagi, a przez to uświadomienie sobie, co się dzieje i z jakiego powodu. Ta świadomość umożliwia akceptację obecnego stanu rzeczy oraz wprowadzenie takiej zmiany, która podniesie komfort życia. Założenia i obserwacje, jakie stoją za tą techniką są następujące: 1. Człowiek może kierować swoją uwagą w dowolny sposób. 2. Świadome kierowanie uwagą umożliwia pożądaną zmianę. 3. Zmiana jest utrudniona lub niemożliwa, jeśli pojawia się ocenianie i brak akceptacji. 4. Uświadamianie sobie bieżącej chwili łączy się z uczuciem wdzięczności. 5. Świadome kierowanie uwagą pozwala na zrozumienie przyczyny i skutku. 6 . Rozumienie siebie wpływa na wzrost rozumienia innych. 
Stworzone na bazie światopoglądu buddyjskiego praktyki mindfulness mają charakter uniwersalny. Techniki intencjonalnego kierowania uwagą mogą być stosowane bez względu na kontekst, miejsce i czas. Rosnącą popularność mindfulness obserwuje się nie tylko w krajach angielskojęzycznych. Treningi praktykowania uważności wprowadza się także poza ośrodkami zdrowia, np. na uczelniach, w szkołach, miejscach pracy, a nawet w policji.

\section{Nauczanie mindfulness w szkołach}

Wprowadzanie mindfulness do szkół wynika z doniesień o skuteczności treningu uważności w różnych obszarach zdrowia psychicznego takich, jak: stres, nadpobudliwość czy niewrażliwość społeczna, z którymi borykają się szkoły w wielu krajach Europy i w USA. Wprowadzanie uważności w szkołach ma charakter profilaktyczny, jak i terapeutyczny. Zakłada się, że jeżeli nauczy się dzieci i młodzież podstawowych zasad higieny psychicznej takich, jak: samoobserwacja, rozumienie przyczyny i skutku, sposobów oddziaływania na myślenie, emocje i zachowania, będzie możliwe wsparcie ich rozwoju osobistego i społecznego, co w konsekwencji przyczyni się do osiągnięcia dojrzałości psychicznej i społecznej, równocześnie prowadząc do spadku występowania zaburzeń psychicznych. Trening uważności, będąc jedną z wielu podejmowanych interwencji w obszarze zdrowia psychicznego, jest zgodny z wytycznymi międzynarodowych organizacji zajmujących się zdrowiem publicznym.

Celem treningu uważności praktykowanego w placówkach edukacyjnych jest również poprawa koncentracji uwagi uczniów w szkole i poza nią, co przełożyć się może na wyniki w nauce i rozwój osiągnięć edukacyjnych uczniów, a w konsekwencji na pracę i życie osobiste.

Praktykowanie uważności mentalnej może pomóc w aktywnym skupianiu uwagi, aktywnym doświadczaniu rzeczywistości, radzenia sobie z problemami, świadomym relaksowaniu i redukcji psychosomatycznych skutków stresu (Kochanowska, 2012). Celem stosowania praktyk uważności jest także nabycie umiejętności „wsłuchania się” w siebie, odczuwania ciała, swoich potrzeb, emocji, myśli i jednocześnie doświadczania $\mathrm{w}$ pełni bodźców $\mathrm{z}$ otoczenia bez ich krytycznej oceny. Trenowanie doświadczania siebie w troskliwy i akceptujący sposób (self-compassion) wydaje się szczególnie ważne w świetle badań pokazujących, że osoby posiadające tę umiejętność lepiej sobie radzą z trudnymi wydarzeniami życiowymi (Allen, Leary, 2010).

Kryteria doboru programów treningu uważności do analizy w niniejszym artykule były następujące: weryfikacja skuteczności oddziaływań danego pro- 
gramu opublikowana w znaczącym czasopiśmie naukowym; nieprzerwana realizacja od momentu rozpoczęcia programu; powszechna dostępność kluczowych materiałów dotyczących programu. Na potrzeby opracowania wybrano sześć programów realizowanych w Wielkiej Brytanii i USA: .b, Paws b, Learning2breath, Inner kids, Mindful school i MindUP (Załącznik 1).

Pierwsze zorganizowane na dużą skalę wprowadzanie programu mindfulness do planu zajęć uczniów rozpoczęło się w 2007 r. w Wielkiej Brytanii. Ogólnokrajowy program pod nazwą .b posiada swój odpowiednik dla młodszych uczniów - Paw b. Wieloletnie doświadczenia realizacji tych programów postanowiono poddać ocenie i w styczniu 2015 r. wdrożono projekt MYRIAD, przygotowany przez zespół naukowców i pracowników, którego koszty wynoszą $10 \mathrm{mln}$ funtów, a którego celem jest m.in. staranne zbadanie tego, jak mindfulness wpływa na młodzież oraz zweryfikowanie skuteczności i opłacalności wprowadzania treningów uważności w szkołach. W Stanach Zjednoczonych mindfulness był wprowadzany oddolnie od roku 2000 przez pasjonatów, między innymi Susan Kainsen Greenlad, która stworzyła program Inner Kids. Inne programy, które zyskały popularność i zostały poddane badaniom skuteczności, to MindUP, stworzony w ramach fundacji Goldie Hawn oraz Mindful Schools, realizowany przez organizację non-profit o tej samej nazwie. Treningi mindfulness wprowadzane są również w: Kanadzie, Australii, Chinach i Serbii (m.in. MindUP).

Treningi mindfulness zazwyczaj prowadzone są przez nauczycieli, którzy odbyli specjalne kursy. Prowadzący powinien być świadomy technik, które przekazuje. Niejednokrotnie wymagane jest ukończenie kursu opartego na MBSR/MBCT, a następnie kolejnego kursu uczącego, jak przekazywać zdobyte umiejętności. Kluczowa jest również własna indywidualna praktyka uważności. $\mathrm{Z}$ analizowanych programów jedynie MindUP nie wymaga takiego przygotowania. Zazwyczaj włącza się treningi uważności w plan zajęć szkolnych w małych grupach. Program treningu mindfulness trwa minimum 6 tygodni i może być kontynuowany dowolnie długo. Pojedyncze spotkania trwają od 10 min do 1 godziny. W czasie zajęć uczniom przekazuje się udokumentowaną naukowo wiedzę dotyczącą pracy mózgu oraz układu nerwowego, prezentując te zagadnienia w sposób atrakcyjny i dostosowany do wieku. Uczniowie dowiadują się o związkach między myśleniem, emocjami i zachowaniami oraz ich wpływie wzajemnym na siebie. Uczą się o tym, jaki wpływ ma człowiek na swoje zachowania i myśli; poznają narzędzia umożliwiające ten wpływ, zapoznają się z technikami samoobserwacyjnymi. Uczniowie mają możliwość wypowiadania się o swoich przemyśleniach i odczuciach. 
Wszystkie programy promują wartości takie, jak: życzliwość, współczucie, odpowiedzialność, cierpliwość i wdzięczność. Uczniowie otrzymują materiały pomocowe na zajęciach. Każdy program ma swoją propozycję ujęcia przekazywanych treści. Nauczyciele na zajęciach z uważności wykorzystują środki dydaktyczne takie, jak: prezentacje multimedialne, postery, materiały dźwiękowe, filmy. Metody jakimi się posługują to m.in.: wykład, ćwiczenia, gry, zabawy i dialog. Zachęca się uczniów do praktykowania uważności poza szkołą.

\section{Efekty nauczania mindfulness w szkołach}

Badania nad efektami nauczania mindfulness prowadzone są od niedawna, jednak uzyskano już wiele wyników świadczących o pozytywnych efektach tej praktyki. W grupach osób dorosłych efekty nauczania mindfulness są potwierdzone wieloma badaniami (z których część wspomniano powyżej). Dokonując przeglądu literatury angielskojęzycznej na potrzeby niniejszego artykułu, znalazłyśmy jeden artykuł będący metaanalizą badań nauczania mindfulness dla dzieci i młodzieży w szkołach oraz w placówkach ochrony zdrowia psychicznego (Zoogman i in., 2014) oraz dwa artykuły prezentujące metaanalizy badań programów nauczania mindfulness w szkołach i przedszkolach (Felver i in., 2015; Zenner in., 2014). Poniżej przedstawiamy najważniejsze wnioski $\mathrm{z}$ tych metaanaliz.

Zoogman i in. (2014) przygotowali metanalizę 20 artykułów, spełniających kryteria włączeniowe, odnoszących się do interwencji nauczania mindfulness i realizowanych w szkołach oraz placówkach ochrony zdrowia. Zagregowano wyniki różnych miar skuteczności interwencji dla poszczególnych badań. Wykazano, że wielkość łącznego efektu w badaniach pierwotnych była na poziomie niskim lub średnim, co wskazuje na przewagę interwencji nauczania mindfulness w porównaniu do innych rodzajów interwencji (np. inne zajęcia szkolne lub zajęcia $\mathrm{z}$ edukacji zdrowotnej). W analizowanych badaniach pierwotnych jako zmienne zależne wzięto pod uwagę szereg miar skuteczności interwencji. Były to zarówno miary obiektywne, tj. wskaźniki psychofizyczne, zadania wymagające koncentracji uwagi i wykonania określonych czynności, jak i miary subiektywne, tj. skale oceny lub samoopisu wypełniane przez nauczyciela, rodzica lub dziecko. W analizowanych badaniach jako zmienne zależne użyto miar symptomów dysfunkcji psychicznych (np. lęk, agresywność), miar umiejętności społecznych, dobrostanu, uwagi, efektów psychofizycznych, uważności (mindfulness) i uwagi (attention). Miary uważności i uwagi obejmowały obiektywne zadania koncentracji uwagi i inwentarze samoopisu uważności. 
Metaanaliza wykazała istotnie wyższy efekt łączny dla zmiennych zależnych mierzonych wskaźnikami dysfunkcji psychicznych w porównaniu do zmiennych mierzonych innymi wskaźnikami. Przeanalizowano także czynniki pośredniczące mające istotny wpływ na wielkość efektów interwencji. Jedynie rodzaj próby okazał się istotny, tj. badania oparte na próbach klinicznych (uczestnicy ze zdiagnozowanym zaburzeniem psychicznym lub objęci opieką w placówce zdrowia psychicznego) w porównaniu do prób nieklinicznych. Dla prób klinicznych ujawniono większy łączny efekt interwencji niż dla prób nieklinicznych.

Metaanaliza przygotowana przez Zennera i in. (2014) zawiera analizę statystyczną miar efektów wyników 24 badań. W badaniach wykorzystano zróżnicowane miary efektów pogrupowane przez Zennera i wsp. na pięć kategorii: funkcjonowanie poznawcze, problemy emocjonalne, czynniki odporności psychicznej, stres i radzenie sobie, oceny osób trzecich. Autorzy metaanalizy podsumowali swoje badanie konkluzją, że interwencje w środowiskach edukacyjnych oparte na mindfulness dają pozytywne rezultaty zwłaszcza w zakresie poprawy funkcjonowania poznawczego i odporności na stres.

Felver i in. (2015) w swoim przeglądzie literatury badawczej odnotowali szereg efektów interwencji opartej na nauczaniu mindfulness w środowisku szkół i przedszkoli. Wiele badań wykazało redukcję aspektów psychopatologii, tj. problemów zachowania $(n=6)$, lęku $(n=3)$, depresji $(n=4)$, zaburzeń afektywnych $(\mathrm{n}=4)$, problemów w zakresie funkcji wykonawczych i uwagi oraz myśli samobójczych $(\mathrm{n}=1)$. W wielu badaniach zaobserwowano wzrost aspektów prospołecznych, chociaż wachlarz efektów był bardzo zróżnicowany i obejmował zaangażowanie w grupie klasowej, regulację emocji, umiejętności społeczne, kompetencję społeczno-emocjonalną, radzenie sobie, pozytywne emocje, optymizm i zachowanie w grupie klasowej. Ponadto cztery badania wykazały korzyści dla uczniów mierzone wskaźnikami fizjologicznymi, a jedno badanie - poprawę samooceny uważności. W żadnym z analizowanych badań nie wzięto pod uwagę danych raportowanych przez szkoły dotyczących osiągnięć szkolnych lub zachowania.

\section{Potrzeby polskiej szkoły a nauczanie mindfulness}

Programy mindfulness w szkołach były dotąd wdrażane głównie w krajach angielskojęzycznych i tam też przeprowadzano badania ich skuteczności. Warunki istniejące w polskim szkolnictwie mają swoją specyfikę i dlatego warto rozważyć, jakie przeszkody mogą utrudnić wprowadzanie programów mindfulness dla dzieci i młodzieży w szkołach i przedszkolach w Polsce. 
Cechą charakterystyczną społeczeństwa polskiego jest dominująca rola religii katolickiej, co wiąże się z przywiązywaniem wagi do katolicyzmu jako elementu środowiska wychowawczego w placówkach edukacyjnych. Dyskusyjny problem, czy uważność jest wprowadzeniem religijności niezgodnej z duchem katolicyzmu, wydaje się być rozwiązany przez to, że kursy certyfikujące mają charakter wyłącznie świecki - odwołują się do uniwersalnych zasobów i umiejętności człowieka. Również przedstawiciele kościoła katolickiego popierają wprowadzenie uważności do szkół, włączając do treningu mindfulness elementy religijne (por. Radoń, 2013, 2014a).

Przeszkodą, która może utrudniać wprowadzenie zajęć z uważności mentalnej do szkół, jest przeciążenie nauczycieli pracą wynikającą z podstawy programowej i dużej liczby spraw priorytetowych, bieżących bądź o charakterze dokumentacyjno-sprawozdawczym. Nie wydaje się praktyczne, aby uważność była wprowadzana do planu lekcji. Natomiast zapoznanie i przeszkolenie możliwie dużej liczby nauczycieli w szkole, która wprowadza trening uważności, może być podejściem właściwym. Nauczyciele, którzy zaczną sami praktykować mindfulness jako element własnego rozwoju osobistego, nie tylko będą w stanie lepiej radzić sobie z przeciążeniem pracą i lepiej gospodarować czasem, ale też będą bardziej chętni do uczenia uważności na swoich lekcjach.

Problemem dla nauczycieli może być też wygospodarowanie środków na pokrycie kosztów certyfikowanych szkoleń, jeśli nie będą one dofinansowane przez pracodawcę. Według raportu TALIS 2013 „głównymi barierami utrudniającymi udział polskich nauczycieli w rozwoju zawodowym są nadal zbyt wysokie koszty oraz brak odpowiedniej oferty" (Hernik i in., 2015, s. 5). Rozsądnym wydaje się przyjęcie założenia, że szkoła, która przystępuje do programu nauczania uważności, stara się o dofinansowanie i zapewnia nieodpłatne szkolenia dla swoich pracowników.

Raporty z ostatnich lat o zagrożeniach w polskiej szkole zwracają uwagę m.in. na przemoc (Nowakowska i in., 2015) oraz różne formy dyskryminacji (Gawlicz i in., 2015). Hernik i in. (2015) raportują wyniki międzynarodowego badania nauczycieli i dyrektorów szkół TALIS 2013. Badania te pokazały, że „polscy nauczyciele są dobrze wykształceni i dobrze merytorycznie przygotowani do swojej pracy, gorzej natomiast jeśli chodzi o umiejętności miękkie zarządzanie klasą, komunikację z uczniami” (Hernik i in., 2015, s. 5). Ponadto zaburzona jest równowaga pomiędzy wymaganiami i wsparciem psychicznym uczniów. Polskie szkoły plasują się wysoko w rankingu pod względem wymagań i dyscypliny, natomiast prezentują wyraźne deficyty, jeśli chodzi o wsparcie i zrozumienie uczniów". Na uwagę zasługuje również fakt, że polscy nauczy- 
ciele rzadziej niż nauczyciele $\mathrm{z}$ innych krajów wypowiadają się otwarcie na temat swoich trudności. O tym, że poziom stresu psychologicznego doświadczanego przez uczniów i nauczycieli w środowisku szkolnym w Polsce jest wysoki, mówią liczne badania, nie tylko te prowadzone w ostatnich latach (Jacennik, Szczepańska, 2007).

W świetle powyżej wspomnianych wyników można sugerować, że wprowadzenie treningów uważności w polskich szkołach mogłoby skutecznie poprawić funkcjonowanie społeczne i odporność na stres zarówno uczniów, jaki i nauczycieli. Zachowania buntownicze i opozycyjne wiążą się m.in. z deprywacją potrzeby autonomii (Erikson, 2004). Trening uważności w dużej mierze opiera się na swobodnych wypowiedziach uczniów. Jeśli wypowiedzi są przyjmowane, a nie oceniane, zaspokajana jest wtedy potrzeba autonomii u wypowiadających się uczniów.

Programy treningu uważności wzmacniają również u praktykującego poczucie zaangażowania, przynależności, odpowiedzialności i troski oraz, towarzyszące im, odczuwanie współczucia. Zaangażowanie i przynależność są potrzebami, które jeśli nie są realizowane, przynoszą w efekcie nieadekwatne i niefunkcjonalne zachowania takie, jak niesubordynacja, przemoc i agresja.

Nauka uważności zwiększa u uczniów wiedzę i rozumienie wpływu myśli na emocje i zachowania, co może stanowić ważny czynnik profilaktyki stanów depresyjnych i lękowych. W depresji charakterystyczna jest tzw. triada depresyjna, tzn. negatywne myślenie o sobie, świecie i przyszłości (Beck, 1979). Myślenie to, podobnie jak w zaburzeniach lękowych, opiera się przede wszystkim na zniekształceniach poznawczych takich, jak generalizacje, np. „nic mi się nie udaje”, oraz osądzanie, krytyk wewnętrzny, np. ,,jestem beznadziejna, znów zrobiłam z siebie idiotkę". Uświadomienie sobie tych niefunkcjonalnych myśli i ich skutków daje w efekcie defuzję, czyli uzyskanie dystansu do swoich myśli. Ten dystans sprawia, że myśli nie wywołują już tak silnych emocji. Praktykowanie uważności prowadzi m.in. do samoobserwacji narzucających się i powracających myśli bez elementu oceny i związanej z nią reakcji emocjonalnej. Techniki mindfulness umożliwiają nabieranie dystansu do własnych przeżyć wewnętrznych, w tym do myśli negatywnych, samokrytycznych, wzbudzających lęk czy smutek.

Podstawowe zadanie szkoły, jakim jest kształcenie uczniów, może być realizowane skuteczniej dzięki m.in. wpływowi treningu mindfulness na umiejętność skupienia. Uwaga jest podstawą procesu uczenia się (Strelau, 2006). Aktywne skupianie uwagi, czyli takie, które podlega woli i może być zgodnie z tą wolą utrzymywane, mimo rozpraszających bodźców, sprzyja optymalnemu wykorzystaniu przez ucznia czasu spędzonego na lekcji. 
Współcześnie, w procesie edukacji, oprócz przekazywania wiedzy i zasad współżycia społecznego, duży nacisk kładzie się na rozwijanie myślenia krytycznego, które pozwala na optymalizację procesu wyszukiwania informacji. Raport z badania TALIS 2013 pokazuje, że większość nauczycieli jest zdania, że w uczeniu ważniejsze są umiejętności wyciągania wniosków i rozumowania niż nabycie szczegółowej wiedzy z danej dziedziny. Jednak polscy pedagodzy rzadziej niż ich zagraniczni koledzy stosują techniki nauczania, które mocno angażują uczniów takie, jak praca w małych grupach lub przygotowanie dłuższego projektu (Hernik i in., 2015, s. 5).

Dla samych nauczycieli prowadzenie treningów uważności stwarza okazję do ćwiczenia umiejętności miękkich, np. okazywania zainteresowania i zrozumienia. Jak pokazują badania w innych krajach, praktykowanie uważności przez nauczycieli może przeciwdziałać wypaleniu zawodowemu, zmęczeniu, problemom z wielością zajęć (Flook i in., 2013). Kluczowym aspektem uważności, jako kompetencji nauczyciela, jest zaangażowanie i gotowość na nowe doświadczenia. Dobry nauczyciel uważności mentalnej to taki, który ją rozumie i praktykuje, nie dlatego, że musi czy powinien, ale dlatego, że chce. Tylko wtedy będzie mógł przekazać tę umiejętność swoim uczniom.

Wprowadzenie uważności mentalnej w polskich placówkach edukacyjnych może ułatwiać to, że większość koniecznych warunków szkoły i przedszkola już spełniają. Są to czynniki takie, jak: zaangażowani i kompetentni nauczyciele, otwarci na zdobywanie kolejnych kwalifikacji (np. certyfikacji trenera mindfulness), kolegialny system zarządzania placówkami edukacyjnymi, utrwalone tradycje oświatowe oraz uznanie społeczne dla roli szkoły jako instytucji życia społecznego. $Z$ doświadczeń innych krajów wynika, że zajęcia uważności łatwo wpisują się w program zajęć lekcyjnych zarówno jako oddzielne zajęcia, jak i dodatkowy element, który można wprowadzić na wszystkich lekcjach.

\section{Wnioski i rekomendacje}

Główne wnioski wynikające z powyższej analizy badań wskazują na istnienie potrzeby prowadzenia programów interwencji psychoprofilaktycznej dla dzieci i młodzieży z wykorzystaniem polskich adaptacji certyfikowanych programów treningu mindfulness. Szczególnie ważne wydaje się zastosowanie doświadczeń uznanych i ugruntowanych programów szkolnych i przedszkolnych przedstawionych m.in. w Tabeli 1. Polski system edukacji przedszkolnej i szkolnej posiada odpowiednie warunki, aby takie programy wprowadzać. Nie wydaje się, aby różnice światopoglądowe, na bazie których wykształciły się te progra- 
my były na tyle istotne, aby mogły zaważyć na ich skuteczności. Przedstawione w artykule wyniki badań wskazują na potencjalne korzyści dla zdrowia psychicznego i rozwoju osobistego, a zwłaszcza kompetencji szkolnych i umiejętności społecznych dzieci i młodzieży.

\section{Bibliografia}

Allen A.B., Leary M.R. (2010), Self-Compassion, Stress, and Coping, „Social and Personality Psychology Compass", nr 4(2), s. 107-118.

Beck A.T., Rush A.J., Shaw B.F., Emery G. (1979), Cognitive Therapy of Depression, The Guilford Press, Nowy Jork.

Chu V. (1993), Psychoterapia Gestalt, Kanon, Łódź.

Cramer H., Lauche R., Paul A., Dobos G. (2012), Mindfulness-based stress reduction for breast cancer - a systematic review and meta-analysis, „Current Oncology”, nr 19(5), s. e343-e352.

Erikson E.H. (2004), Tożsamość a cykl życia, Zysk i S-ka, Poznań.

Felver J.C., Celis-de-Hoyos C.E., Tezanos K., Singh N.N. (2015), A systematic review of mindfulness-based interventions for youth in school settings, „Mindfulness”, $\mathrm{nr} 7$ (1), https://www.researchgate.net/publication/273349460_A_Systematic_Review_of_ Mindfulness-Based_Interventions_for_Youth_in_School_Settings, dostęp: 24.04.2016.

Flook L., Goldberg S.B., Pinger L., Bonus K., Davidson R.J. (2013), Mindfulness for teachers: A pilot study to assess effects on stress, burnout, and teaching efficacy, „Mind, Brain and Education", nr 7(3), s. 182-195.

Gawlicz K., Rudnicki P., Starnawski M. (2015), O budowaniu edukacji antydyskryminacyjnej w systemie edukacji formalnej w Polsce. Raport z badań, Towarzystwo Edukacji Antydyskryminacyjnej, Warszawa.

Hernik K. Malinowska K., Piwowarski R., Przewłocka J., Smak M., Wichrowski A. (2015), Polscy nauczyciele i dyrektorzy w Międzynarodowym Badaniu Nauczania i Uczenia się TALIS 2013, Instytut Badań Edukacyjnych, Warszawa.

Jacennik B., Szczepańska J. (2007), Aby stresu było mniej, „Psychologia w Szkole”, nr 3, s. 89-96.

Kabat-Zinn J. (2013), Życie piękna katastrofa. Mądrościa ciała i umystu możesz pokonać stres, choroby i ból, Czarna Owca, Warszawa.

Kabat-Zinn J., Massion A.O., Kristeller J., Peterson L.G., Fletcher K.E., Pbert L., Lenderking W.R., Santorelli S.F. (1992), Effectiveness of a meditation-based stress reduc- 
tion program in the treatment of anxiety disorders, „American Journal of Psychiatry”, nr 149(7), s. 936-43.

Kabat-Zinn J., Wheeler E., Light T., Skillings A., Scharf M.J., Cropley T.G., Hosmer D., Bernhard J.D. (1998), Influence of a mindfulness meditation-based stress reduction intervention on rates of skin clearing in patients with moderate to severe psoriasis undergoing phototherapy (UVB) and photochemotherapy (PUVA), „Psychosomatic Medicine", nr 60(5), s. 625-32.

Kochanowska Kaian E. (2012), Uważny nauczyciel, „Psychologia w szkole”, nr 3.

Krajewska J. (2016, 29 luty). Czym jest Analiza transakcyjna? - Uczeniem się autonomii. Inspeerio, http://inspeerio.pl/czym-jest-analiza-transakcyjna-uczeniem-sie-autonomii. html, dostęp: 24.10.2016.

Kristeller J.L., Hallett C.B. (1999), An Exploratory Study of a Meditation-based Intervention for Binge Eating Disorder, „Journal of Health Psychology”, nr 4(3), s. 357-363.

Marlatt A. (2002), Substance Abuse Treatment and the Stages of Change, „Addiction”, nr 97(5), s. 607-608.

Namysłowska I. (2013), Zdrowie psychiczne dzieci i młodzieży w Polsce-stan rozwoju opieki psychiatrycznej i zadania na przyszłość, „Postępy Nauk Medycznych”, nr 1, s. 4-9.

Narodowy program zdrowia na lata 2016-2020. Ministerstwo Zdrowia. Warszawa 2015. Projekt.

Nowakowska A., Przewłocka J. (2015), Szkoła oczami uczniów: relacje z nauczycielami i kolegami oraz przemoc szkolna, Instytut Badań Edukacyjnych, Warszawa.

Radoń S. (2013), Uważność jako ponadkulturowe wyzwanie dla polskiej edukacji, w: N. Majchrzak, A. Zduniak (red.), Edukacja międzykulturowa w warunkach kultury globalnej. Od rozważań definicyjnych do praktycznych zastosowań. Edukacja XXI w., T 1/30, Wydawnictwo Wyższej Szkoły Bezpieczeństwa, Poznań.

Radoń S. (2014), Pięciowymiarowy Kwestionariusz Uważności-polska adaptacja Five Facet Mindfulness Questionnaire, „Roczniki Psychologiczne”, nr 17(4), s. 711-735.

Radoń S. (2014a), Uważność jako medytacja w edukacji: fakty i mity, w: Współczesne zagrożenia: fakty i mity, KUL, Lublin, s. 299-317.

Segal Z.V, Williams J.M.G., Teasdale J. (2002), Mindfulness-Based Cognitive Therapy for Depression: A New Approach to Preventing Relapse, Guilford Press, New York.

Strelau J. (red.) (2006), Psychologia, t.1, GWP, Gdańsk.

Tabak I. (2014), Zdrowie psychiczne dzieci i młodzieży. Wsparcie dzieci i młodzieży w pokonywaniu problemów, „Studia BAS”, nr 2(38), s. 113-138. 
Wendt, K. (2015, 12 luty). Uważność, jako trzecia fala terapii poznawczo - behawioralnej, Strefa Psychoterapii i Rozwoju, http://spir.pl/uwaznosc-jako-trzecia-fala-terapiipoznawczo-behawioralnej/, dostęp: 24.10.2016.

Williams J.M.G., Russell I., Russell D. (2008), Mindfulness-Based Cognitive Therapy, „J Consult Clin Psychol”, nr 76(3), s. 524-529.

Wolańczyk T. (2002), Zaburzenia emocjonalne i behawioralne w populacji młodzieży szkolnej w Polsce, Wydawnictwa Akademii Medycznej w Warszawie, Warszawa.

World Health Organization (2005), WHO Mental Health Policy and Service Guidance Package: Child and Adolescent Mental Health Policy and Plans, World Health Organization, Geneva.

Zenner C., Hermleben-Kurz S., Walach H. (2014), Mindfulness-based interventions in schools - a systematic review and meta-analysis, „Frontiers in Psychology”, nr 5, http:// www.ncbi.nlm.nih.gov/pmc/articles/PMC4075476/, dostęp: 24.04.2016.

Zoogman S., Goldberg S.B., Hoyt W.T., Miller L. (2014), Mindfulness interventions with youth: A meta-analysis, „Mindfulness”, nr 6, https://mindfulnessinschools.org/wp-content/uploads/2013/09/zoogman.pdf, dostęp: 25.04.2016. 